\title{
POSTMODERN TENDENCIES IN UKRAINIAN BALLET IN SOVIET TIMES IN THE 60S-80S OF THE $20^{\text {th }}$ CENTURY
}

\author{
ПОСТМОДЕРНІСТИЧНІ ТЕНДЕНЦІї \\ УКРАЇНСЬКОГО БАЛЕТУ В РАДЯНСЬКУ ДОБУ \\ 60-80-Х РОКІВ ХХ СТОЛІТТЯ
}

\section{Larysa Markevych ${ }^{1}$}

DOI: https://doi.org/10.30525/978-9934-26-001-8-3-2

Abstract. The article deals with the artistic language evolution in the Ukrainian national ballet performance in terms of the creative process and the gained image-result - the author's and the performer's reflection (certain specifics of thinking), directly creative action, the form of existence of a choreographic work.

The well-known choreographers-directors' creative activity of Ukrainian performances of the above period has been analyzed, the peculiarities of the work of each of them have been revealed. Emphasis is focuses on expanding the thematic range of ballet works in the practice of the national stage.

The specifics of the work of Ukrainian composers in the field of the national ballet genre have been identified; the evolution of the artistic language in ballet in historical retrospect has been defined.

It has been emphasized that an important aspect for the choreographic language formation of the Ukrainian national ballet performance was the embodiment of the historical and the heroic themes. The canonical feature of the stylistic certainty of the Ukrainian national ballet performance is the combination of the heroic motives and the lyrical-romantic perspective of the image of opposing forces.

Having analyzed significant historiographical material, it has been proved the difference between the national ballet performance of the $60 \mathrm{~s}$ and 80 s of the twentieth century from the similar productions in other republics.

Based on a comprehensive analysis of a number of ballet performances of the $60-80$ s of the twentieth century, the following functions of the

\footnotetext{
${ }^{1}$ Candidate of Arts, Associate Professor of Choreography, Rivne State Humanities University, Ukraine.
} 
artistic language in the structure of this genre have been identified: expressive, emotional, figurative, symbolic, and thematic contrast. It is the transformation of the functions of the artistic language that leads to changes in the genre and the style format of a ballet performance.

The aim of the research is to substantiate the peculiarities of postmodernist tendencies that influenced the artistic language of the Ukrainian national ballet performance in the Soviet era of the $60-80$ s of the XX century. The subject of the study is the artistic language of the Ukrainian national ballet performance of 60-80 years of the XX century. The objectives of the research are to study the evolution of the national stylistic features of the artistic language in the structure of the Ukrainian national ballet performance of the $60-80 \mathrm{~s}$ of the XX century; to reveal the integral specificity of the artistic language of the Ukrainian ballet performance as a symbolic, figurative-semantic, expressive and technical system (according to the similarity of the principles of historical formation).

In accordance with the objectives of the study, the following methods have been used: general scientific - in the analysis of the genre modifications of ballet, the evolutional stages of the choreographic means of expression, various manifestations of synthesis of stylistic trends and arts, a systematic approach to the development and enrichment of Ukrainian dance; historical - to define the sequence of conditions of the artistic language formation and development in the Ukrainian ballet performance, the creation of the national performing and choreographic style; analytical - in the study of art literature in the relevant direction, in the analysis of the potential meaning of the choreographic forms in ballet performance at the level of the artistic language of the genre; culturological - in highlighting the trends and the patterns that contributed to the transformation of the Ukrainian ballet in the context of new socio-cultural trends in choreographic art at this stage of the historical period; biographical in considering the activities of the personalities of the prominent Ukrainian choreographers, ballet dancers, composers; theoretical - in the study of the theoretical foundations of the artistic language of the choreographic art.

The influence of the postmodernist tendencies responded to the development of the Soviet ballet (including Ukrainian ballet), that reached the opportunity in the mode of accelerated development, in the "condensed" artistic space, to inscribe in the world context its own specifics of the laws of the national choreographic-historical process. Postmodernism 
successfully embraces the various levels of the real life in the Ukrainian society: the "Khrushchev thaw", the "sixties", Brezhnev's stagnation of the 1970s and intellectual dissidents, Gorbachev's "perestroika" of the 1980s and the artistic underground that led to the pluralism and video eclecticism. Themes of Ukrainian ballet of the Soviet era were studied by Pavlyuk T. [4], Stanishevsky Yu. [6-8], Stankovych-Spolska R. [9-11].

\section{1. Ветуп}

Загальна тенденція для українського балетного театру 50-х рр. розкриття духовного світу людини - набула відображення в драматургії та хореографічній мові української балетної вистави у намаганнях відійти від побудови вистави за принципами хореодрами (нові редакції «Лілеї» та «Лісової пісні», нові балети «Маруся Богуславка» А. Свєчникова, «Сойчине крило», «Хустка Довбуша» А. Кос-Анатольського та ін.), у більш глибокому синтезі класичного й національного танців із введенням елементів, характерних для танцювальної культури західних регіонів України. Посилилися процеси драматизації та симфонізації танцю, в яких хореографічна лексика українського танцю набула значення «спільного знаменника» всієї образної сфери художньої мови балетної вистави: елементи народного танцю забарвлювали класичну лексику в характеристиках позитивних героїв, а у поєднання 3 пантомімою, адаптованою для використання в класичному балеті,окреслювали негативних героїв. Можна сказати, що завершився в цілому цикл функціонування романтичного канону, в якому відбулося більш чи менш вдале підпорядкування етнохарактерного матеріалу усталеним закономірностям музичного та хореографічного професіоналізму.

Вплив постмодерністичних тенденцій відізвався на розвиткові радянського балету (українського в тому числі), що отримав можливість у режимі прискореного розвитку, у «згущеному» мистецькому просторі, вписати у світовий контекст власну специфіку закономірностей національного хореографічно-історичного процесу. Постмодернізм вдало охоплює різні рівні реального буття українського соціуму «хрущовської відлиги», «шістдесятництво», брежнєвської стагнації 70-х та інтелектуальне дисидентство, горбачовську «перебудову» 80-х і мистецький андеграунд, що призвели у 90-х роках до ідеологічної дезорієнтованості та плюралістичного еклектизму. 


\section{2. Постмодерністичний національний канон на тлі фольклорного коду}

Світові тенденції постмодернізму (термін Ф. Джеймсона, 1964 р.), певної «гіперреальності» 3 притаманними їй стильовою «всеядністю», стимулювали створення в мистецтві індивідуалізованих, локальних знакових систем, «авторських словників», оригінальних підходів у роботі з фольклором. Українське національне балетне мистецтво в світлі нефольклорної хвилі постмодернізму збагатилося новою якістю: не одномірним, багатоаспектним поданням етнохарактерного матеріалу з розкриттям його як автентичних коренів, так і сучасного бачення національного образу світу. Почалося творення нового постмодерністичного національного канону з підпорядкуванням елементів різних хореографічних технік природі фольклорного коду, фольклорних танцювальних лексем та розкриттям за їх допомогою нерозгорнутих раніше глибинних смислів.

Активізація соціокультурного стану в Україні у 60-ті pp. ХХ ст. спрямували розвиток художньої мови в балетних виставах у напрямі більш широких узагальнень, стилізації елементів народного танцю, відмови від прямого цитування фольклорних джерел. Характерною для цього періоду стала постановка вистав декількох типів: а) на сюжети 3 життя українців-сучасників, в яких невеликими «вкрапленнями» з'являлись ознаки національної танцювальної культури («Орися» А. Кос-Анатольського, «Пісня про дружбу» Ю. Щуровського, «Поема про Марину» Б. Яровинського, «Слава космонавтам» Ю. Бірюкова, «Торжество кохання» Ю. Знатокова, «Чорне золото» В. Гомоляки та ін.); б) з'явилася нова балетна музика українських композиторів, що вимагала створення відповідних танцювальних образів-носіїв певних емоційно-психологічних барв, що дозволяли більш заглиблено передавати всі колізії вистави («Тіні забутих предків» В. Кирейка, балетмейстер Т. Романова, 1960 р., м. Львів; «Лілея» К. Данькевича, балетмейстер А. Шекера, 1964 р.).

Наслідком цих процесів стало виникнення нової, більш багатозначної танцювальної стилістики, що синтезувала виразність класичного та народного українського танцю. Звертаючись до національної тематики, українські балетмейстери утверджують власний почерк у використанні традиційних танцювальних засобів, долаючи ілюстра- 
тивність та поверховість естетики хореодрами. Паралельно з цим процесом здійснюються інтенсивні пошуки адекватних засобів виразності для втілення нової тематики [4].

Філософія «хрущовської відлиги» потребувала оновлення балетного репертуару напрямом створення вистав на сьогочасну тему. Їх відсутність частково відшкодовувала композиторська творчість. У 60-ті роки з'являється нова українська балетна музика (Ю. Рожавська, Б. Буєвський, М. Сильванський, Б. Яровинський та ін.), проте, перші спроби модернізації засобів, на яких трималася естетика хореодрами, виявилися невдалими («Торжество кохання», «Блакитна стрічка»-хореографія М. Трегубова) [4].

Ситуація почала змінюватися лише після того, як була здійснена друга редакція балету «Чорне золото» В. Гомоляки за хореографією П. Вірського, якому вдалося об'єднати лексику класичного танцю 3 виражальними засобами ансамблевих танцювальних форм, які складалися в межах народного сценічного танцю. Цей напрям продовжили львівські балетмейстери М. Заславський та А. Шекера у постановці балету «Орися» А. Кос-Анатольського[ 4].

Вагому роль в оновленні українського балетмейстерського мистецтва 60-х років відіграли дослідні знахідки І. Бєльського, В. Васильова, О. Виноградова, Н. Касаткіної, які прагнули подолати антагонізм між танцем і пантомімою музичними засобами, відтворюючи їх зміст шляхом поєднання різних танцювальних прийомів з елементами пантоміми у нових хореографічних формах - одноактних балетах на українській сцені (балети-новели «Слава космонавтам» Ю. Бірюкова, балетмейстер С. Дречин; «Дзвін Вітчизни» А. Хачатуряна, балетмейстер О. Лапаурі). Але національна тематика в одноактних балетах втілена не була.

Суттєві зрушення спостерігаються наприкінці 60-х років, коли з'являються вистави «Жовтнева легенда» Л. Колодуба, створена П. Вірським у керованому ним Ансамблі танцю та «Поема про Марину» Б. Яровинського у постановці В. Вронського. Ці одноактні балети на сучасну тему стали певним етапом у становленні самобутнього українського хореографічного мистецтва: реалізовано оновлення тогочасної балетної стилістики через синтез різножанрових танцювальних елементів - танцю-модерн і народної хореографічної лексики (П. Вірський), класичного і народних танців із ритмізованою пантомімою (В. Вронський). 
Дійсно інноваційними стали хореографічні композиції, здійснені А. Шекерою («Досвітні огні» Л. Дичко), якому вдалося створити узагальнені пластичні образи, адекватні композиторському задуму. Але таких вистав було небагато, бо переважну більшість їх становила суміш пантомімічних прийомів - «драм-балету» та запозичень з авторського танцювального словника постановок І. Бєльського, В. Васильова, Ю. Григоровича, Н. Касаткіної.

\section{3. Радянський балет в інтерпретаціях українських балетмейстерів}

Аналізуючи досягнення української балетмейстерської творчості наступних років, слід зазначити, що на українській сцені активізується опанування зарубіжного досвіду, яке відбувається опосередковано, через повтор-інтерпретацію постановок радянського балетного театру загалом. У них простежується прагнення розширити репертуарні обрії цього виду мистецтва та осучаснити класичну спадщину. Цей принцип знайшов подальший розвиток у творчості українських балетмейстерів: В. Вронського, О. Дадішкіліані, М. Заславського, А. Пантикіна, А. Шекери, які прагнули, спираючись на визнану хореографію, змінити ії шляхом використання засобів виразності, що підказувала музична партитура балету. Так, узагальнююче виразне начало та психологічно-філософська багатогранність хореографічного втілення музики С. Прокоф'єва, яку продемонстрував у своєму постановочному рішенні балету Л. Лавровського «Ромео і Джульєтта» В. Вронський, відкрили шлях для створення на українській сцені чисельних авторських інтерпретацій цього балету: як ліричної драми характерів - в А. Пантикіна, узагальненого образу, стилізації середньовічного способу життя - у тлумаченні М. Заславського, філософської трагедії - у хореографічному баченні А. Шекери. Найяскравіше балетмейстерське новаторство демонструють інтерпретації музики С. Прокоф'єва. Прагнення розкрити суть музичного задуму спонукало балетмейстерів на пошуки шляхів оновлення класичної танцювальної лексики (хореографічні втілення музики балету «Попелюшка»: балет-поема у постановці Одеського театру, балетмейстер О. Виноградов; ліричний монолог-сповідь в інтерпретації М. Арнаудової, постановка Харківського театру опери і балету; філософська казка у балетмейстерському рішенні А. Шекери, Львів. 
Ю. Станішевський зазначав, що основними тенденціями 70-80 pp. $\mathrm{XX}$ ст. у розвитку національного балетного мистецтва були «пильна увага до реалістичних традицій українського й усього радянського балету, прагнення до відродження драматургічної дієвості хореографічного спектаклю, створення різних за жанрами і стильовими особливостями вистав, що органічно поєднували на конкретній ідейно-тематичній основі музичну, театральну, хореографічну образність» [6, с. 239]. Значну роль у цьому процесі відіграє композиторська творчість.

Нові принципи побудови музичної форми, нові засоби музичної образності, які декларували балетні партитури С. Прокоф’єва, А. Хачатуряна, К. Караєва, А. Петрова, Р. Щедріна та ін., вимагали від хореографів переосмислення традиційних підходів до засобів побудови танцювального малюнку вистави. В цих виставах кристалізуються елементи художньої мови нового естетичного рівня, які прогнозують подальший розвиток українського балетмейстерського мистецтва: поліфонізація загального малюнка балетної вистави (постановки I. Чернишова та Л. Воскресенської в Одесі й Дніпропетровську), симфонізація побудови танцювальної драматургії у постановках А. Шекери (в Київському та Львівському театрах).

Інтенсивне накопичення власного національного творчого досвіду у 70-ті роки сприяло оновленню жанрової палітри балетмейстерського мистецтва. 3'являються балети - ліричні поеми («Сім красунь» К. Караєва у постановці М. Трегубова), балети - психологічні драми («Стежкою грому» К. Караєва, хореограф А. Шекера), балети баладного характеру («Легенда про любов» А. Мелікова у постановці А. Шекери) та інше [4].

Слід зазначити, що розвиток синтезу класичного та українського танцю став повільнішим, оскільки для помітного оновлення танцювальної лексики не вистачало запозичення виразних засобів нових систем - танцю модерн, джазового танцю (серед поодиноких прикладів «Світанкова поема» на музику В. Костенка) та лише формувалися нові нефольклорні підходи до використання художнього матеріалу в хореографічному мистецтві, здатні осучаснити естетично-образну й знаково-символічну систему художньої мови української балетної вистави.

Накопичення значних досягнень у верифікації різних інтерпретаційних прочитань, на жаль, небагатьох українських балетів «золотого фонду» 
хореографічного мистецтва призвело до актуалізації тенденції орієнтації балетмейстерів на акторські можливості та індивідуальні якості виконавців, що позначилося варіативністю здійснених постановок. Зберігаючи загальні контури хореографії, українські балетмейстери оновлюють їх відповідно до можливостей та темпераменту виконавців провідних партій. Цей напрям став провідним у діяльності українських балетних труп протягом 70-80-х років XX ст. Але «визрівання» нової симфонічної хореографічної вистави, що відбувалося в музичному мистецтві та інша тенденція 70-х pp. - спроба через мистецький синтез об'єднати в художній мові вистави всі іiі елементи навколо провідної ідеї, прагнення до опосередкованого використання засобів виразності, запозичених із суміжних видів мистецтва - музики, театру, живопису, підготувало підгрунтя для подальшого розвитку українського балетмейстерського мистецтва та художньої мови української балетної вистави у 80-90-х роках.

Загальна характеристика розвитку балету в той період дозволяє виокремити тенденції, які спрямовували творчість балетних колективів України:

- зміцнення зв'язків у створенні концепції балету між композиторами і лібретистами, композиторами та хореографами-експериментаторами (балети за мотивами повісті Ч. Айтматова, давньогрецьких джерел, «переклади» на хореографічну мову оперних постановок «Материнське поле» К. Молдобасанова, «Медея» Р. Габічвадзе, «Орфей та Евридіка» М. Боярчикова та ін.);

- оновлення підходів до академічних версій класичного балету, прагнення утвердити авторське мистецьке обличчя через неординарне тлумачення традиційних балетмейстерських технологій;

- тяжіння до експериментаторства, синтезу мистецтв, сміливих лексичних поєднань. Так, образно-виражальну палітру українського балетмейстерського мистецтва збагатили так звані «датські» балети 80-х років - балети, що ставилися театрами на державне замовлення. Незважаючи на те, що всі вони мали пропагандистський характер та відверте ідеологічне спрямування, балетмейстерські рішення в них не обмежувалися сакраментальними засобами танцювальної лексики. Нерідко ці рішення живилися аналогами образних втілень у суміжних видах мистецтв, скажімо, у кінематографі: опосередковано через однойменний кіносценарій Є. Габриловича в балеті В. Губаренка 
«Комуніст» із хореографісю В. Смирнова-Голованова (Одеський театр опери та балету), або безпосередньо за участю відомого кінорежисера Ю. Ільєнка у створенні монументальної героїко-революційної вистави «Прометей» (музика Є. Станковича, балетмайстер А. Шекера) [2, с. 5].

- активне опанування досвіду сучасних різновидів танцю модерн. Одним із головних напрямів у балетмейстерських пошуках другої пол. 80 - початку 90-х рр. XX ст. можна назвати становлення нових прийомів до синтезу класичних та модерністських виразових засобів, відкритих М. Бежаром, Р. Петі, Дж. Ноймайсром, У. Кіліаном та іншими балетмейстерами. Засвоєння естетики модерну й постмодерну відбувалось неоднаковими шляхами: цитування, варіювання-стилізації, діалог-компроміс різних хореографічно-стильових версій втілення ідейного задуму балету («Світанкова поема» Г. Майорова, музика В. Косенка, «В ім’я життя» А. Шекери, музика Д. Шостаковича), запозичення домінант драматургії з суміжних видів мистецтв: музики, кіно, телебачення та стильових засобів різних, далеких від балету, танцювальних жанрів, народних і сучасних побутових.

- Переважна більшість нового покоління балетмейстерів були випускниками факультетів балетної режисури Москви і Ленінграду.

Щоб привернути увагу до проблеми виховання продовжувачів традицій В. Вронського, П. Вірського, А. Шекери, в Україні організовуються республіканські конкурси балетмейстерів-постановників. Проведення конкурсів сприяло зростанню чисельності імен молодих постановників на афішах театрів України (у Донецькому театрі - балетмейстер I. Колюбакіна, у Харківському театрі - хореограф В. Шкілько, у Одеському театрі - балетмейстери А. Шевельова, В. Смирнов-Голованов).

Показовим прикладом сприймалася в той період творчість А. Шекери, який прагнув урізноманітнити класичні побудови українського балету через самобутні інтерпретації класичної спадщини та використання сучасних прийомів, апробованих модерною балетною практикою вітчизняних та зарубіжних балетмейстерів. Створення сучасних прочитань репертуарних творів на основі грунтовного аналізу хореографії, музики, сценографії, загального художнього оформлення вистави, активна кооперація з диригентами С. Турчаком, О. Рябовим, В. Кожухарем - напрям, який репрезентує мистецтво А. Шекери, не був єдиним у хореографічній палітрі українського балету [4]. 
Сучасними забарвленнями іiі доповнює творчість Г. Майорова, зорієнтована на відчуття хореографічної драматургії у модерних танцювальних ритмах (вистава «Чіпполіно» К. Хачатуряна), В. Ковтуна, який прагне відновити класику у первісному вигляді, проголошуючи плюралізм у виборі варіантів та чистоту стильових рішень, В. Литвинова, що намагається шляхом рівноправного злиття елементів класичного танцю, фольклорного та модерн-танцю осучаснити балетну мову, додати їй виразності слова (балет «Ніч перед Різдвом» Є. Станковича).

Дослідницькі вистави 80-х років стали для багатьох молодих балетмейстерів напрямом, який виховув у них бажання до сприйняття неоднакових хореографічних систем і танцювальних форм. В руслі формування постмодерністичного національного канону української національної балетної вистави посилення національних кадрів у балетмейстерському виконавському складі та поєднання їх потенціалу 3 музичними напрацюваннями актуалізувало професіоналізацію неофольклористичних тенденцій.

Неофольклоризм проникає й вкорінюється у музичний театр України ще $з$ другої пол. ХХ ст. завдяки впливу світових творчих досягнень. Якщо фольклоризм - це родове поняття, що охоплює всі творчі форми спілкування з фольклором в академічному мистецтві, починаючи від XVIII ст. до сучасності, незалежно від часових, національних, стильових та інших орієнтирів, то неофольклоризм виступає як цілком визначене в своїх межах стильове поняття, що належить до художньої культури XX ст. Л. Хрістіансен вводить у науковий обіг також поняття «нова фольклорна хвиля», що розглядається як відповідний до більш локального національно-соціального музично-сценічного явища радянської культури (української, зокрема) $60-80-$ х років XX ст. [9, с. 254-263].

Неофольклорна жанрова парадигма українського балетного театру $\mathrm{XX}$ ст. як складне і неоднозначне явище історично-процесуального виявлення зазнала впливу двох провідних різноспрямованих тенденцій, сформованих в музичному мистецтві: «академізації фольклору» (Л. Яначек, С. Прокоф’єв, Б. Лятошинський, А. Калнинь, Я. Мединь) і «фольклоризації жанру» (Б. Барток, М. Леонтович, частково Дж. Гершвін, Є. Станкович). Остання тенденція, на відміну від першої, яка фольклоризує балетний жанр «із середини» (через цитування, переінтонування, 
стилізацію тощо), зводиться до фольклоризації «ззовні», через надання балетній формі в цілому (в т. ч. іiі образній та музичній драматургіï) певних стійких прикмет фольклорних жанрів. Саме фольклоризація балетного жанру, що «визрівала» у нечисленних балетних творах 60-80-х рр., стала основною тенденцією розвитку експериментальних видів сучасної української вистави вже з 90-х рр. («Вікінги» та «Ніч перед Різдвом» Є. Станковича, «Володимир Хреститель» та «Фрески Софії Київської» В. Кікти, нові редакції «Лілеї» і «Лісової пісні»).

Одною з перших ознак розвитку неофольклоризму другої пол. XX ст. є посилення в художній мові української національної балетної вистави ролі знаків національної характерності не лишена образно-драматургічному рівні, а й в цілому на рівні балетної форми. Так, опора на глибинні образи і традиції національної культури, національного мислення і психології визначають

розширення скарбниці жіночих образів та жіночих хореографічних форм. Жіночі хореографічні форми в нових виставах «Торжество кохання» Ю. Знатокова (1960р., Львів, балетмейстер М. Трегубов), «Тіні забутих предків» В. Кирейка (1963р., Київ, балетмейстер Н. Скорульська), «Досвітні вогні» Л. Дичко (1967р., Львів, балетмейстери М. Заславський і А. Шекера), «Відьма» В. Кирейка (1967 р., Львів, балетмейстери М. Заславський і А. Шекера), «Орися» А. Кос-Анатольського (1968 р., Львів, балетмейстери М. Заславський і А. Шекера), «Пісня синього моря» Б. Буєвського (1967 р., Одеса, балетмейстер М. Трегубов), «Каменярі» М. Скорика (1969 р., Київ, балетмейстер А. Шекера) грунтуються на цілісності драматургії всього сценічного твору й індивідуально розвиваються у виконавських концепціях артистів балету, що свідчило про розширення сфери рефлексивного досвіду та виконавських можливостей в комунікативній моделі балетмейстер - артист за рахунок впливу неофольклористичних тенденцій зокрема.

Інноваційна тенденція академізації фольклору в українському балетному театрі 60-80-х рр. відбивалися в постановках А. Шекери - основоположника масштабного поліфонічного й багатопланового балету. Постановки А. Шекери об’єднують романтично-поетичну природу балетного танцю з тонким психологізмом, живою й позитивною енергетикою, ментальною щирістю, монументальністю, філософ- 
ською глибиною національного мислення. Модифікація художньої мови в національних балетних виставах А. Шекери отримала втілення у сміливому переінтонуванні елементів народного танцю, прагненні до образно-метафоричних пластичних узагальнень, підкресленого розмежування протиставних образних сфер та різнопланового втілення в танці характерів героїв.

Психологізація хореографічної мови поглиблювалась у зв'язку 3 посиленням ролі у балетмейстерській презентації виконавської інтерпретації, яка набула функції доповнення балетмейстерського хореографічного тексту та демонструвала національну манеру виконання: поєднання в пластичному малюнку партії блискучої техніки академічного класичного й українського народного танців, акторської майстерності, глибокого розуміння національного характеру. В цілому можна говорити про формування поняття виконавського фольклоризму як особливої «форми засвоєння живого етнотрадиційного інтонування» $[1$, с. 9], яке є основою для встановлення логічного зв'язку з художніми принципами виконавських інтерпретацій в українських балетних виставах.

Аналіз художньої мови в постановках балетних вистав А. Шекери («Каменярі» М. Скорика, «Відьма» В. Кірейка, «Досвітні вогні» Л. Дичко, «Ольга» С. Станковича) свідчить про застосування нових модифікаційних підходів: звільнення від елементів танцювальної жанровості, конкретно-зображувального звукопису та розширення виражальної палітри чоловічого класичного кордебалетного танцю, який збагатився лексикою модерну та постмодерну («Каменярі»); досягнення більш високого рівня узагальнення пластичних інтонацій українського хореографічного фольклору, прояв нових смислових і стильових якостей - концентрованого драматизму, виразного i тонкого психологізму, пристрасно-експресивного насичення («Відьма», «Досвітні вогні»); згущення драматургічної насиченості не лише за рахунок стилістичного урізноманітнення художньої мови вистави (переінтонування елементів народного танцю, їх поєднання з класичною лексикою та формами сучасного балету), а й її граничної індивідуалізації (хореографічні лейттеми), показу різних граней чуттєвості й емоційності у вираженні особистісного начала головних героїв (полісемантика образу княгині у балеті «Ольга»). 


\section{4. “Фольклоризація” балетного жанру в радянську добу}

Прояв в українській балетній виставі тенденції «фольклоризаuіiі жанру», яка зводиться до фольклоризації через надання балетній формі стійких прикмет фольклорних жанрів, у 60-80-ті рр. спостерігається у балетній музиці Є. Станковича - справжньому «сховищі первинних концептів» для втілення української національної ідеї засобами синтетичної пластичної мови класичного, народного та сучасних видів танцю. Дослідження музично-сценічного доробку композитора у світоглядному вимірі виявляє ідею, драматургію, логічну структуру та концепцію художньої мови сучасної української балетної вистави, де музика набуває програмного значення для формування знаково-символічної, образно-виражальної, технічно-інтерпретаційної якостей нової хореографічної мови. Музична партитура Є. Станковича в балетній виставі переймає на себе функцію сценарної мови, стає виразником розгортання сценічної дії, фактично текстом національного значення, що диктує балетмейстеру-постановнику певні логічні та естетичні вимоги.

Балетна творчість Є. Станковича, «сучасного Гоголя», «нового українського Стравінського» [5], композитора великого драматичного обдарування, в сучасній науковій літературі висвітлена переважно у музикознавстві, аспекти балетмейстерсько-хореографічного втілення здебільшого розкриваються у великій кількості публікацій рецензійного характеру та наукових роботах, статтях, присвячених в цілому музичній творчості автора. Однією 3 грунтовних робіт, де найбільш повно освітлюється проблематика балетного театру Є. Станковича, $\epsilon$ дослідження Р. Станкович-Спольської [9-11].

Здобутки українського балетного жанру, достатньо високе жанрове тло, представлене роботами В. Кирейка, О. Костіна і особливо В. Губаренка, стали важливим фактором творчої стимуляції інтересу С. Станковича до українського балету.

Аналіз музичного стилю та музичної мови, властивостей композиторського мислення Є. Станковича дозволяє відмітити чіткість візуального бачення матеріалу, що звучить, образну конкретність, символічну картинність і зображальну змістовність тематизму, ясну драматургічну спрямованість музичного розвитку і особливу пластичну природу інтонації. Показовим $\epsilon$ той факт, що, власне, балетна 
творчість провідного українського композитора неухильно еволюціонувала від написання фольк-опери «Цвіт папороті» (1979 р.; в інтерпретації 2003 р. - фольк-опера-балет) - до фольк-балету «Майська ніч» (1986 р.; прем’єра балету у Київському муніципальному академічному театрі опери та балету для дітей і юнацтва -1989, у Національній опері України - 1998 р.).

У загальному жанровому комплексі музичного театру Є. Станковича відбувається взаємопроникнення ознак фольк-опери та фольк-балету, що підкреслюється спільними змістовно-драматургічними й композиційно-інтонаційними засобами. Вже у фольк-балеті «Майська ніч» балетмейстер-постановник В. Гаченко, розуміючи призначення пластично-хореографічної мови достовірно і вичерпно розшифрувати глибокі змісти текстових шарів гоголівського тексту (набуває сакрального значення в розкритті національної епіко-історичної та побутово-фантазійної образності) та пісенно-танцювального фольклорного тексту, робить спробу виявити й смисли авторського прочитання. Головний же результат оперно-балетної асиміляції - поява нового жанрового різновиду синтетичної фольк-вистави,що розкриває національні епіко-історичні та побутово-фантазійні образи.

В авторській інтерпретації А. Шекери балету «Ольга» С. Станковича (Київ, балетмейстер А. Шекера, лібрето Ю. Іллєнка, диригент С. Турчак, художник Ф. Нірод, в головній партії Р. Хілько) у 1981 р. уже присутні ознаки зовнішньої фольклоризації, але презентовані в музичній драматургії балету образні сфери - героїко-драматична, любовно-лірична та народно-обрядова здебільшого вирішуються академізацією синтетичної художньої мови. У протиставленні задумів композитора і балетмейстера (монолітне, наскрізного розвитку музично-симфонічне полотно та циклічність самодостатніх балетних епізодів) смислова єдність надається за допомогою прийому метафоризації сценічного компоненту вистави, хореографічної мови зокрема.

Виконавський стиль Р. Хілько та В. Литвинова демонстрував наскрізну чуттєвість, що пронизував як ліричну, так і динамічно-напружену інтонаційну основу твору. Індивідуалізація виконавського стилю відбувалася по лінії вираження світу героїв через внутрішнє переживання, особливо критики відзначали «першу скрипку спектаклю» - Раїсу Хілько. Хореографічна мова головних героїв втілюється 
у пластичному прояві їх особистісного начала. Саме тому вплетені в масові сцени адажіо та варіації солістів є означенням ключових моментів їх життя (самоствердження чи відчаю, перемоги чи поразки).

Історико-побутовий характер балетної вистави підкреслено привнесенням в історичну елегію ознак конкретної, переконливої оповіді про людські якості видатної історичної особистості. Урізноманітнення хореографічної лексики відбувається за рахунок розширення етнічної складової: елементів слов'янських хороводів (імітація язичницької обрядовості), войовничого переплясу кочівників-печенігів, експансивних дикунських рухів древлян.

Надзвичайно високий рівень емоційної напруги балетмейстер досягає, обравши лаконічну, але експресивну, динамічну мову, в якій кожний елемент стає пристрасно-смисловою інтонацією, а хореографічний час суттєво ущільнюється, позбавляючись усього зайвого, другорядного. Відсутність дрібної балетної техніки, статичного позування, використання великих жете і арабесок як найуживаніших компонентів для танцювальних зв'язок, надання кожному па і навіть найпростішим пор-де-бра драматичного й експресивного звучання дозволяє досягнути необхідного хореографічного тонусу. В кульмінаційній зоні вистави дуетні сцени Ольги та Ігоря підкреслюють діалогічну єдність героїв пластичними засобами «римування» елементів жіночого і чоловічого танцю.

Балет Є. Станковича «Ніч перед Різдвом» - приклад поєднання стилістичних та жанрових ознак комплексу сценічних жанрів професійного музичного мистецтва і рис фольклорного вертепно-маланкового обрядового дійства, зразок оновлення і адаптації традиції у світоглядній системі суспільства $80-\mathrm{x} \mathrm{pp.} \mathrm{XX} \mathrm{ст.} \mathrm{Жанрова} \mathrm{спорідне-}$ ність 3 оперетою та мюзиклом підкреслена в музиці демократизмом інтонацій, зверненням до побутуючих і стилізованих ужиткових різновидів легкої розважальної музики (вальс, галоп, чардаш, фокстрот, танго, музика паркових і духових оркестрів,різновиди ліричних тем, стилізація опереткової увертюри-попурі), що здійснена в балеті на рівні тембрової драматургії та хореографії. В основі балету (лібрето О. Бєлінський та В. Литвинов) - однойменна повість М. Гоголя з циклу «Вечори на хуторі біля Диканьки», яку свого часу використовували для своїх опер П. Чайковський («Черевички»), М. Римський-Корса- 
ков («Ніч перед Різдвом»), М. Лисенко («Різдвяна ніч»). С. Станкович сформував власну концепцію задуму з чіткими естетичними критеріями втілення гоголівської образної національної поетики: використати іiі могутній театрально-видовищний потенціал, передати все багатство звичаїв, вірувань, фантастики, відтворити картини сільської різдвяної ночі з щедрівками й колядками та фантастичні образи нечистої сили, небесних стихій. Відповідно, художня мова вистави розкриває різні образні сфери вистави, різні стильові пласти. Необхідність оперування різними стильовими пластами зумовило жанрову особливість вистави - балет-пастиччіо. Музична драматургія розкриває три інтонаційно-образні сфери: жанрово-побутову, характерну, комедійну народні сцени; бально-дансантні, до яких належать пародійно-пристрасне танго Імператриці з коханцями, парадний полонез придворних, «Лебідь» Сен-Санса; епізоди умовно-нейтральні. Їх поєднання надає драматургії яскравої образності й театральності. В балетмейстерській рефлексії В. Литвинова (1989 р., 1993 р., у 2008 р. - до 200-річчя від дня народження М. Гоголя) для кожної інтонаційно-образної сфери та персоніфікованого образу - Дяка, Голови, Оксани, Вакули - вибудуваний пластичний малюнок ролі, що зберігається протягом вистави (хореографічний лейттематизм).

Поява фольк-опери «Цвіт папороті» Є. Станковича пов'язана 3 близькими до неї за жанрово-стильовим спрямуванням творами Л. Грабовського, М. Скорика, Л. Дичко. «Цвіт папороті» Є. Станковича став етапом високохудожнього узагальнення багатоскладової національної традиції та водночас результатом винятково оригінальної авторської позиції щодо сучасної композиторської нефольклорної методології, яка полягає в фольклоризації звукового матеріалу. Композитор зробив художнє відкриття, поєднавши одночасно відкритий цитатний етнографізм («відкрита» манера співу народного хору) та найсучасніші засоби симфонічного втілення в руслі логіки нефольклорної стильової оріснтації .

Спираючись на ідею автохтонності народного мистецтва, композитор застосував метод збереження первісної чистоти фольклорного наспіву із подальшим зануренням його у складно організовану темброво-сонорну симфонічну тканину, але за умов непорушності ладотональної та ритмо-мелодичної функційності пісенної теми. Відтак 
затвердився провідний, «тезовий» стилістичний принцип твору - nолiпластовість. Ще однією образно-символічною похідною від нефольклорного мислення на композиційному рівні стає ідея «намиста», на яке наче нанизуються певні пісні, сюжети і смисли (перлами в цьому уявному намисті стали кращі репертуарні номери хору ім. Г. Верьовки, поєднані з сюжетним каркасом гоголівської повісті «Тарас Бульба»).

$€$. Станкович переосмислив узагальнений романтичний національний образ XIX ст. від С. Гулака-Артемовського, П. Ніщинського, М. Калачевського, М. Лисенка - до Л. Ревуцького та Б. Лятошинського: лірико-побутова складова масово-національного образу в його авторському баченні поступається місцем більш ємному ментально-образному складу. Зокрема, в фольк-опері С. Станковича «Цвіт папороті» національний образ постає комплексним і багатомірним, таким, що тяжіє до універсальності історичного змісту. Це проявляється завдяки принципу узагальнених характеристик, відсутності образно-особистісної персоніфікації. Наявні окремі персонажі «Цвіту папороті» піднімаються до значення художніх типів високого етично-естетичного гатунку (Батько, Мати, Кобзар, Козак, Дівчина).

Новаторські риси лібретто, де підкреслюється показова для мистецтва постмодерністичної доби розшарованість змісту (дія відбувається в кількох різних і хронологічно розділених культурно-часових площинах, що між собою сюжетно не перетинаються, а координуються на ідейно-символічному та композиційно-інтонаційному рівнях). Зазначена розшарованість відбивається і на зовнішній структурі пісенно-хореографічного тексту, який майже не містить повністю завершених блоків, а натомість тяжіє до фрагментарності, специфічної поетично-фольклорної колажної фантазійності.

Серед канонічних засад композиції оперно-балетної будови відзначимо триактну структуру, наявність композиційних арок між крайніми актами, своєрідну скорочену (динамічну) репризу з функцією афористичної коди. Ознаки виходу за межі композиційного канону в музичній партитурі визначає Р. Станкович-Спольська: «двовимірна» в часовому плані концентрично-сферична композиція (передбачає щоразу нове поглиблення образного розвитку, новий рівень художньо-інтонаційного узагальнення) та композиційний дуалізм (суттєва структурно-композиційна відмінність крайніх актів опери по відношенню до 
середнього: в I та III актах композитор застосовує суттєво оновлений, «осучаснений» номерний принцип організації оперного цілого, структурною одиницею якого виступає сцена або картина, то в II акті, спираючись на логіку сонатно-симфонічного циклу, використовує наскрізний принцип жанрової побудови; Одиницею структури при цьому стає той чи інший варіант купальського обряду, представлений крупними «симфонізованими» драматургічними блоками) [11].

Кожний фольклорний знак-орієнтир - пісня або танець (фольклорний комплекс, в тому числі обрядовий, або, наприклад, інструментальний - «троїсті» музики) є запорукою структурної, драматургічної та інтонаційної єдності твору, основою образно-інтонаційного творення в кожний конкретний момент сценічної реальності (ознака зовнішньої фольклоризації).

Яскраво-новаторською композиційною знахідкою «Цвіту папороті», яка переконливо відповідає духу сучасного, посткласичного художнього мислення, $\epsilon$ наявність «непрямих знаків» візуального типу - картин-символів (Є. Станкович - С. Лисик): кожна сцена (оперна або інструментально-балетна) символізує певні національні універсалії i «зчіплюється» 3 наступними сценами в самостійний образний ряд на основі лібрето. Така специфіка композиційної системи споріднена 3 ментально-генетичною для українського мистецтва поетичністю художнього сприйняття, певною кінематографічно-монтажною картиною українського національного буття. Відбувається наближення до унікальної естетики українського народного символізму, якому, поряд із поетичністю та фантазійністю, притаманні нестримна експресія розгортання, вибуховий темперамент, театральність зовнішніх форм, схильність до драматичного загострення змісту.

Для усвідомлення розвитку хореографічного тематизму в художній мові вистави важливо проаналізувати новаторські підходи композитора до музичної мови. С. Станкович організує звуковий матеріал за номерним принципом у декілька способів: системою внутрішньо-актових сюжетно-композиційних арок (в I дії - Вступ у характері думи (№ 1) і передфінальна дума «Зажурилась Україна» (№ 10), «Жарти» (№ 5) і «Козачок» (№ 7), формуванням образно-споріднених міні циклів (№№ 2 і 3 - «Майдан» і «Муштра», експресивно-ліричні №№ 8 i 9 - «Колискова» і «Ой пущу я кониченька в саду») та спон- 
танними проявами анти образності. На рівні хореографічної мови за допомогою цих прийомів можливо сміливо оперувати головними образними етносферами величної героїки, народно-жартівливої та лірико-пісенної стихії та синтезувати симетрично-репризний, інтонаиійно-узагальнюючий та наскрізний типи хореографічного розвитку.

Знаковими в I дії окреслені образ Кобзаря (семантика естетичного канону українського романтичного мистецтва XIX ст.) та узагальнено-типізований образ зла (активно-динамічне розгортання в ряді балетів XX ст.)

У II дії - «Купало» - розгортається динамічно-наскрізний принцип композиційної будови, суттєво укрупнюються розділи-блоки форми. В цій дії презентована цілком завершена модель народного образу світу, яка вирізняється логічною гармонійністю і філософською глибиною у співставленні трьох компонентів, трьох образно-інтонаційних сфер-світів: реального земного світу («Людські Купала»), темного демонологічного антисвіту («Відьомські Купала»), та проміжного між ними - світу фантазійно-побутового («Русальні Купала»), однаково спорідненого з двома попередніми. Застосування всебічного драматургічного контрасту (зміна сюжетної канви, перехід в іншу історичну площину та психологічну атмосферу) «переключає» $з$ історичної конкретики, піднесеної патетики та звукової «жорсткості» реальних, драматично-дієвих картин Запорізької Січі з першої картини на панування давньої архаїки, невимовної мелодико-пластичної краси, природності емоцій, лірично-чуттєвої насиченості купальських дійств.

Принцип поступового сценічного розгортання музичного та хореографічного матеріалу призводить до оформлення низки великих масових сцен, а також яскраво-драматичної кульмінації («Ой, глибокий колодязю» на початку «Русальних Купал»).

III дія «Цвіту папороті» побудована за картинно-номерним принципом організації, в основі побудови фіналу - монтажний принцип. Циклічно-симфонічна логіка музичного розгортання зміцнює внутрішню композиційну мотивацію спільності між тотально-контрастними крайніми актами і проміжним «Купалом», два останніх номери (№ 3 «Гопак» $\mathrm{i}$ № 4 «Фінал») разом виступають епілогом-кодою всього твору.

Моделюючи цілісну балетну виставу, можна передбачити, що в іiі художній мові знайдуть втілення деякі загальні ознаки симфонічного 
мислення С. Станковича: лейттематизм та лейтмотивізм, репризно-тематична арочність, активна трансформація тематизму, семантично-образна ієрархія та багатофункціональність загального тематичного комплексу. Центральні тематичні зони твору (визначаються за музично-тематичними пластами музичної партитури) - це лейттема козацтва та масово-обрядовий комплекс «Купало» (в музичній партитурі «хоровий комплекс» [11]. Фонові тематичні пласти - танцювальні або пісенні комічно-жартівливі теми дієво-побутового походження, які створюють «адекватне звукове середовище» (глісандуючий пласт та індивідуально-тембровий пласт рибальських дзвіночків), утворюють «яскраво-контрастну образну й тематичну опозицію»до провідних епіко-драматичних лейттематичних комплексів (коломийка, троїсті музики, козачок, сатиричний вальс) [11].

Особливу увагу приділяємо останній версії «Цвіту папороті» - виставі А. Авдієвського-А. Рубіної у жанрі фольк-опери-балету, поставленій на сцені Національної опери (2003р.), яка є показовою для нинішнього стану авторського тексту, що потенційно містить у собі завершений задум «повнометражної» української національної балетної вистави: фольк-опера продовжує існувати в сучасному музично-театральному процесі не стільки завдяки версіям-редакціям, a, скоріше, всупереч їм, зберігаючи на майбутнє завдяки могутньому інтонаційному потенціалу самої музики міцність і цільність драматургічної основи та жанрової концепції.

А. Рубіна $з$ артистами Національного заслуженого академічного народного хору ім. Г. Верьовки втілила нову редакцію II дії фольк-опери-балету С. Станковича «Цвіт папороті» - «Купало». Про цю постановку критики писали: «Особливо ж новітньою і домінантною $\epsilon$ постановка і хореографія талановитого сучасного балетмейстера Алли Рубіної, яка фактично змінила лібрето і створила оперу-балет, перенісши події з XVII-XVIII століть у прадавні часи». Балетмейстер гармонійно об'єднала лексику сучасного танцю 3 елементами давньої фольклорної семантики, сформувавши свою специфічну мову художніх образів. Спираючись на музику Є. Станковича, відобразила у стилістиці балету магічність обрядової дії, сформувала хореографічні особливості впізнаваної хореографічної мови. У балетному тексті незвично відображено тему кохання, яке проходить процес 
страждання і випробування отримує прощеня [3, с. 82]. Балетмейстерському «почерку» А. Рубініної притаманні загострена характерність, легкість хореографічних па та піднесеність. Її характерною особливістю, як хореографа-балетмейстера, $є$ тонка образність народного танцю, в який вона майстерно поєднує з сучасними постмодерними течіями різні образні прояви. У народній хореографії постмодерн розкривається у зверненні до історичної, язичницької тематики. Це дає змогу природньо з'єднати сучасну лексику з елементами давньої фольклорної семантики [3, с. 83]. В інтерпретації балетмейстера друга дія опери-балету Є. Станковича отримала нове життя, А. Рубіна сміливо реалізувала поєднання професійних, танцювально-фольклорних та народно-символічних канонів, що свідчить про присутність сучасного розуміння зрілого неофольклористичного мислення в хореографії.

«Цвіт папороті» інтегрує в собі універсальний художній образ України, розкриває величезний етичний та естетичний потенціал національної ідеї і водночас містить достатній комплекс виражальних засобів інтонаційної реалізації. Елемент «генетичного авторського забарвлення» (термін Є. Станковича) стає визначальним у творі, генерує весь стрій образності та драматургії, скеровує музичний розвиток на розкриття головної художньої мети - трансформувати фольклорну ідею на предмет професійно-довершеного мистецтва світового рівня. Адекватно реалізований засобами хореографічної мови, твір Є. Станковича може стати уособленням високої естетичної норми постмодерністичного художнього канону української національної балетної вистави якцілісний жанровий продукт сучасного європейського неофольклоризму, вирішальним фактором якого стане фольклорний пріоритет мислення на всіх рівнях творчого задуму - від ідейного змісту до нюансів композиторсько-балетмейстерської технології. Нова індивідуальна парадигма високої естетичної норми української балетної музики, започаткована $€$. Станковичем та визнана у світі, чекає на своє повноцінне хореографічне втілення.

На початку 90-х рр. автентичність української хореографії зумовила своєрідність розвитку національної балетної вистави в напрямку майже одночасного масованого проникнення в ії жанрово-стилістичну та образно-смислову основу елементів модерну і постмодерну. Синтез нових елементів в національній балетній виставі простежується 
на ідейно-смисловому рівні та на рівні техніки виконання (синтез-цитування класичного, сучасного, українського, народного, бального, архаїчного та ін. видів хореографічного мистецтва), що характерно для постмодернізму; продовжується творення нової нормативності, в якій всі елементи нових хореографічних технік набувають фольклорної природної органіки та сприяють розгортанню раніше невиявлених національних образів, смислів, контекстів.

\section{5. Висновки}

У трансформації художньої мови від першої спроби постановки української національної балетної вистави виокремлено наступні тенденції розвитку: психологізація пластичної мови балетних вистав; синтез виразних засобів класичного і народного танців, збагачений акторською грою; симфонізація танцювальної мови, підкорення народної образності смисловим і виражальним завданням - фольклорні елементи як «ембріон образу чи певного настрою» в процесі розробки піддаються істотному внутрішньому переконструюванню, інколи своєрідній переорієнтації, спрямованій на вираження нового смислу, не передбаченого народним першоджерелом.

Органічне сполучення характерних стильових ознак українського народного танцю з новими формами хореографічного мислення, що актуалізують ключові моменти 3 проблематики сучасності, дозволяє розширити зміст поняття «українська національна балетна вистава» як хореографічний твір, в якому у результаті опосередкованого впливу літературного першоджерела на музичну складову балетного синтезу або у разі відсутності сюжету (безсюжетний балет) відбувається своєрідна «нейтралізація» літературного змісту. Тоді музична основа балету, що містить національні ознаки музичної мови та музичного змісту, стає визначальним фактором для формування нової хореографічної мови - синтезу класичного, українського народного та сучасного танцю.

Трансформація естетичного канону української національної балетної вистави 60-80-х рр. від національного романтичного до національного постмодерністичного вплинула на структурні та смислові ознаки системи художньої мови (мовного коду). На образно-смисловому рівні мовного коду відбулася трансформація протиставних емоційно-образ- 
них сфер реального і фантастичного з поступовою концентрацією драматизму, виразного психологізму, пристрасної експресії, що призвело до граничної образно-смислової індивідуалізації, втіленої у хореографічному лейттематизмі. На знаковому рівні поєднання уніфікованих хореографічних та національних фольклорних мовних кодів починало свій розвиток від паралельного співіснування, формування фольклорно-сценічної знакової системи до прояву знаків національної характерності на рівні образно-драматургічному, в цілому на рівні балетної форми, у вигляді ментально-психологічної знаковості. Розвиток художньої мови української національної балетної вистави на рівні виражальних засобів здійснювався через симфонізацію музичної мови та вдосконалення внутрішніх якостей синтезу засобів хореографічної виразності класичного та народного танцю, синтезу класичного, фольклорного та модерн-танцю. На технічно-інтерпретаційному рівні мовного коду української національної балетної вистави виявлено тенденцію до формування виконавського фольклоризму, становлення національного виконавського стилю.

\section{Список літератури:}

1. Бенч-Шокало О. Український хоровий спів. Актуалізація звичаєвої традииії : навч. посіб. Київ : ред. журналу Український світ, 2002. 440 с.

2. Конькова Г. Центральний герой - комуніст. Комуніст на сцені Одеського театру. Культура і життя. 1986. 9 лют.

3. Маркевич Л.А. До питання про модернізацію художньої мови балетних вистав 60-80 років XX століття. Українська культура. Минуле, сучасне, иляхи розвитку. зб. напрям : “Мистецтвознавство”. Рівне : РДГУ, 2018. Вип. 26. С. 75-83.

4. Павлюк Т. Українське балетмейстерське мистецтво другої половини XX ст. : дис. ... канд. мист. : 17.00.01 / Держ. акад. кер. кадрів культури і мистецтв. Київ, 2005. 199 с.

5. Сімнадцять миттєвостей Євгена Станковича [Інтерв'ю]. Львів : Глас, 2014. URL: https://www.youtube.com/watch?v=w_2-LNagiQc\&ab_channel

6. Станішевський Ю. Національний академічний театр опери та балету України ім. Т. Шевченка: історія і сучасність. Київ : Муз. Україна, 2002. 734 с.

7. Станішевський Ю.П. П. Вірський - народний артист СРСР. Київ : Держ. вид-во образотворчого мистецтва і муз. літ. УРСР, 1962. 46 с.

8. Станішевський Ю. Розквіт українського балету. Київ : Рад. Україна, 1961. $48 \mathrm{c}$.

9. Станкович-Спольська Р. Неофольклоризм в опері XX століття і “Цвіт папороті" Є. Станковича. Музика у просторі культури. Наук. вісник НМАУ ім. П.І. Чайковського. Вип. 33. Київ, 2004. С. 254-263. 
10. Станкович-Спольська Р. Фольк-опера Є. Станковича «Цвіт папороті» як факт національної історії. Київське музикознавство. Вип. 8. Київ : КДВМУ, 2002. C. $180-188$.

11. Станкович-Спольська Р. «Цвітпапороті» Євгена Станковича: проблема жанру : автореф. дис. ... канд. мист. : 17.00.03. Київ, 2005. 20 с.

\section{References:}

1. Bench-Shokalo O. (2002). Ukrainian choral singing. Actualization of customary tradition: textbook. way. Kyiv: ed. magazine Ukrainian world. (in Ukrainian)

2. Konkova H. (1986). The central character is a communist. Communist on the stage of the Odessa Theater. Culture and life. (in Ukrainian)

3. Markevych L.A. (2018). On the question of modernization of the artistic language of ballet performances of 60-80 years of the twentieth century. Ukrainian culture. Past, present, ways of development. zb. direction: "Art History", 26, 75-83. (in Ukrainian)

4. Pavliuk T. (2005). Ukrainian choreographic art of the second half of the XX century. Extended abstract of candidate's thesis. Kiev: NAKKKiM. (in Ukrainian)

5. Stankovych Ye. (2014). Seventeen moments of Yevhen Stankovych. Retrieved from: https://www.youtube.com/watch? $\mathrm{v}=\mathrm{w}$ _2-LNagiQc\&ab_channel (in Ukrainian)

6. Stanishevskyi Yu. (2002). National Academic Opera and Ballet Theater of Ukraine named after T. Shevchenko: history and modernity. Kyiv: Mus. Ukraine. (in Ukrainian)

7. Stanishevskyi Yu. (1962). PP Virsky - People's Artist of the USSR. Kyiv: State. type of fine arts and music. years. USSR. (in Ukrainian)

8. Stanishevskyi Yu. (1961). The heyday of Ukrainian ballet. Kyiv: Rad. Ukraine. (in Russian).

9. Stankovych-Spolska R. (2004). Neo-folklore in the opera of the twentieth century and "Flower Fern" by E. Stankovich. Music in the space of culture. Science. Bulletin of NMAU named after P.I. Tchaikovsky, 33, 254-263. (in Ukrainian)

10. Stankovych-Spolska R. (2002). E. Stankovych's folk opera "Fern Flower" as a fact of national history. Kyiv musicology, 8, 180-188. (in Ukrainian)

11. Stankovych-Spolska R. (2005). "Tsvitpaporoti" by Yevhen Stankovych: a problem of genre. Extended abstract of candidate's thesis. Kiev: NAKKKiM. (in Ukrainian) 